\title{
KESESUAIAN HIDROGRAF SATUAN SINTETIK TERHADAP HIDROGRAF SATUAN TERUKUR(STUDI KASUS SUB SUB DAERAH ALIRAN SUNGAI PEDINDANG BAGIAN TENGAH)
}

\author{
Gustama \\ Mahasiswa Jurusan Teknik Sipil Univesitas Bangka Belitung \\ Email :tama.tekniksipil@yahoo.com \\ Fadillah Sabri \\ Staf Pengajar Jurusan Teknik Sipil Universitas Bangka Belitung \\ Email : sabrifadillah@yahoo.com \\ Donny Fransiskus Manalu \\ Staf Pengajar Jurusan Teknik Sipil Universitas Bangka Belitung \\ Email : donny_fm@yahoo.com
}

\begin{abstract}
Flooding can be caused by the inability of the river to accommodate the flow of water that passes through the river so that the water overflows. A widely used method for analyzing river flow for flood forecasts is hydrograph unit. The hydrograph unit is a direct runoff hydrograph that can be created when there are AWLR record data, debit measurements and rainfall data. Synthetic Unit Hydrograph (SUH) is a unit hydrograph derived based on river data in the same watershed or nearby watershed but has the same characteristics, ie HSS Gama I, HSS Nakayasu, Limasan HSS, HSS Snyder and HSS SCS. Of the two hydrographs, there will be suitability of the hydrograph form that is going to be made. Sub territory of Pedindang River Basin has four flood incidents, namely, date 23-24 February 2016; March 2-3, 2016; March 3-4, 2016; and date 5-6 March 2016. In the analysis of each flood event, the peak discharge of synthetic unit hydrograph is very different from the peak discharge of the measured unit hydrograph. The average peak discharge of synthetic unit hydrograph occurs in the range of 2 or 3 hours, while the measured unit hydrograph of Pedindang River occurs in the range of 7 or 8 hours. In four flood events it is stated that, HSS Gama I approaches RMSE value (validation <10\%) to HST form of Pedindang River with value: RMSE incidence I (23,601\%); RMSE incidence II (16.315\%); RMSE incidence III (50,400\%); RMSE incidence IV (22.322\%). With this result, it is stated that there is no synthetic unit hydrograph model that has compatibility with the measured unit hydrograph of Pedindang River.
\end{abstract}

Key Word: flood hydrograph, synthetic unit hydrograph, RMSE 


\section{PENDAHULUAN}

Daerah Aliran Sungai (DAS) adalah suatu wilayah daratan yang secara topografik dibatasi oleh punggungpunggung gunung yang menampung dan menyimpan air hujan untuk kemudian menyalurkan ke laut melalui sungai utama (Asdak, 2014). Daerah Aliran Sungai (DAS) dapat digunakan sebagai batas kajian suatu penelitian, mengingat DAS merupakan suatu sistem yang kompleks.

Ilmu yang mempelajari air dalam segala bentuk (cairan, gas, padat) pada, dalam dan di atas permukaan tanah. Termasuk didalamnya adalah penyebaran, daur dan perilakunya, sifat-sifat fisika dan kimianya. Serta hubungannya dengan unsur-unsur hidup dalam air itu sendiri disebut dengan hidrologi (Asdak, 2014). Apabila dilihat dari pernyataan ini, hidrologi adalah ilmu yang tepat mengkaji masalah-masalah yang berkaitan dengan air, salah satunya masalah banjir. Oleh karena hal ini, debit aliran sungai merupakan hal yang sangat penting untuk dikaji dalam prakiraan banjir. Metode yang banyak digunakan untuk menganalisis debit sungai untuk prakiraan banjir adalah hidrograf satuan.

Hidrograf satuan adalah hidrograf limpasan langsung (direct runoff hydrograf) yang dihasilkan oleh hujan efektif yang terjadi merata di seluruh DAS dengan intensitas tetap dalam suatu satuan tertentu, yaitu untuk satuan hujan 1 $\mathrm{mm} / \mathrm{jam}$. Hirograf satuan dapat dibuat apabila tersedia data seperti data rekaman AWLR (Automatic Water Level Recorder), data pengukuran debit juga data hujan.
Hidrograf Satuan Sintetik (HSS) adalah hidrograf satuan yang diturunkan berdasarkan data sungai pada DAS yang sama atau DAS terdekat tetapi memiliki karakteristik yang sama. Dalam penelitian dilakukan analisis pemodelan hidrograf satuan sintetik yang dibuat dengan menggunakan karakteristik DAS untuk mencari kesesuiaan model hidrograf satuan manakah yang sesuai dengan hidrograf satuan terukur di Sub Sub DAS Pedindang, model hidrograf satuan sintetik dibatasi dengan hanya menggunakan HSS Snyder, Nakayasu, Gama I, Limantara, SCS.

Sungai Pedindang merupakan Sub Sub DAS Baturusa. Sungai Pedindang yang dibatasi oleh tinjauan lokasi yaitu pada outlet yang terletak pada stasiun pengukuran tinggi muka air mempunyai luas DAS $35,14 \mathrm{~km}^{2}$ dengan panjang sungai $15,93 \mathrm{~km}$ yang membentang dari Desa Mangkol sampai Desa Parit Lalang yang terdapat alat AWLR. Sungai inilah yang menjadi bahan untuk melakukan pengamatan karena pada kawasan ini tidak tersedia pengukuran-pengukuran langsung mengenai hidrograf banjirnya.

\section{LANDASAN TEORI}

\section{A. Siklus Hidrologi}

Siklus hidrologi merupakan proses kontinyu dimana air bergerak dari bumi ke atmosfer dan kemudian kembali kebumi lagi (Chow, 1998 dalam Triatmodjo, (2014)).

\section{B. Daerah Aliran Sungai (DAS)}

Daerah Aliran Sungai (DAS) adalah wilayah daratan yang secara topografik 
dibatasi oleh punggung-punggung gunung yang menampung dan menyimpan air hujan kemudian menyalurkannya ke laut melalui sungai utama.

\section{Hujan}

Presipitasi adalah turunya air dari atmosfer ke permukaan bumi, yang bisa berupa hujan, hujan salju, kabut, embun dan hujan es (Triatmodjo, 2014). Mengingat bahwa di daerah Indonesia dan lokasi penelitian adalah daerah iklim tropis, maka presipitasi dalam konteks daerah tropis sama dengan curah hujan.

\section{Infiltrasi}

Infiltrasi adalah proses aliran air (umumnya berasal dari curah hujan) masuk kedalam tanah. Proses mengalirnya air hujan ke dalam tanah disebabkan oleh tarikan gaya gravitasi dan gaya kapiler tanah (Asdak, 2014).

\section{Pengukuran Infiltrasi}

Ada tiga cara untuk menentukan besarnya infiltrasi menurut Knapp, (1978) dalam Asdak, (2014):

a. Simulasi di laboratorium.

b. Menggunakan alat infiltrometer.

c. Teknik pemisahan hidrograf aliran dari data aliran air hujan.

2. Indeks Infiltrasi ( $\left.\Phi_{\text {indeks }}\right)$

Indeks infiltrasi adalah laju rerata kehilangan air karena infiltrasi, sedemikian sehingga volume air hujan yang lebih dari laju tersebut adalah sama dengan aliran permukaan (Triatmodjo, 2014), dapat dihitung dengan persamaan berikut:

$$
\text { Indeks } \Phi=\frac{F}{T r}=\frac{P-Q}{T r}
$$

dengan:

$F \quad=\quad$ infiltrasi total $(\mathrm{mm})$

$P \quad=$ hujan total $(\mathrm{mm})$

$Q=$ aliran total $(\mathrm{mm})$

$\operatorname{Tr}=$ waktu terjadinya hujan (jam)

\section{E. Hidrometri}

1. Pengukuran Kecepatan Aliran Air Pengukuran kecepatan arus secara langsung dapat dilakukan dengan menggunakan pelampung, yaitu dengan mengukur selang waktu yang diperlukan untuk oleh pelampung untuk menempuh suatu jarak tertentu, dan dapat dihitung dengan persamaan berikut:

$V=\frac{L}{t}$

dengan:

$V=\operatorname{kecepatan}(\mathrm{m} / \mathrm{det})$

$L \quad=\operatorname{jarak}(\mathrm{m})$

$t \quad=$ waktu (detik)

\section{Hitungan Debit Aliran}

Soewarno (2013), memberikan teori untuk menghitung debit. Debit sungai dapat dihitung dengan cara mengukur luas penampang basah dan kecepatan alirannya, dengan persamaan berikut:

$Q=\sum(a . v)$

$v=k \cdot V_{p}$

dengan:

$Q=$ debit sungai total $\left(\mathrm{m}^{3} /\right.$ det $)$

$a=$ luas bagian penampang basah

$v=$ kecepatan aliran rata-rata pada bagian penampang basah $(\mathrm{m} / \mathrm{det})$

$k=$ faktor koreksi $(0,85$ menurut Triatmodjo, 2014)

$V_{p}=$ kecepatan lintasan pelampung $\left(\mathrm{m}^{3} / \mathrm{det}\right)$ 


\section{Persamaan Lengkung Debit}

Soewarno (2013) menyatakan kurva lengkung debit dapat dihitung dengan metode logaritmik, dengan persamaan umum berikut:

$Q=K\left(H-H_{0}\right)^{n}$.

dengan:

$Q \quad=\operatorname{debit}\left(\mathrm{m}^{3} / \mathrm{d}\right)$

$H \quad$ =tinggi muka air (m)

$H_{0} \quad$ =tinggi muka air pada saat aliran nol (m) ( saat $\mathrm{Q}=0$ )

$K, n$ =bilangan konstanta

Semua data pengukuran debit digambarkan pada kertas grafik logaritmik. Pilih harga debit $\mathrm{Q}_{1}, \mathrm{Q}_{2}$ dan $\mathrm{Q}_{3}$ dari kurva lengkung debitnya, dan harga $\mathrm{Q}_{2}$ ditentukan dari persamaan ratarata geometris sebagai berikut:

$Q_{2}=\left(Q_{1} \times Q_{3}\right)^{0,5}$

Penentuan harga $\mathrm{H}_{0}$ dapat ditentukan dengan tiga cara, yaitu coba-ulang (tial and eror), aritmatik dan grafis. Untuk penelitian ini harga $\mathrm{H}_{0}$ ditentukan dengan metode aritmatik dengan persamaan sebagai berikut:

$H_{0}=\frac{H_{1} H_{3}-H_{2}{ }^{2}}{H_{1}+H_{3}-2 H_{2}}$

Untuk mencari $K$ dan n dapat dibantu dengan dua persamaan dibawah ini:

$\sum(y)-m \log k-n \sum(x)=0$

$\sum(x y)-\sum(x) \log k-n \sum\left(x^{2}\right)=0$

dengan:

$\sum(\mathrm{y})=$ jumlah nilai $\log \mathrm{Q}\left(\mathrm{m}^{3} / \mathrm{d}\right)$

$\sum(\mathrm{x})=$ jumlah nilai $\log \left(\mathrm{H}-\mathrm{H}_{0}\right)(\mathrm{m})$

$\sum\left(x^{2}\right)=$ jumlah nilai kuadrat dari $\mathrm{X}$ $\sum(\mathrm{xy}) \quad=$ jumlah nilai $\mathrm{X}$ dikalikan $\mathrm{Y}$

$\mathrm{m} \quad=$ jumlah pengamatan

\section{F. Hidrograf}

Hidrograf adalah kurva yang memberikan hubungan antara parameter aliran dan waktu (Triatmodjo, 2014). Parameter tersebut bisa berupa kedalaman aliran (elevasi) atau debit aliran, sehingga terdapat dua macam hidrograf yaitu hidrograf muka air dan hidrograf debit.

1. Hidrograf Satuan Metode Collins

Hidrograf satuan ditarifkan sebagai hidrograf limpasan langsung (direct runoff hydrograf) yang dihasilkan oleh hujan efektif yang terjadi merata di seluruh DAS dengan intensitas tetap dalam satu satuan tertentu.

\section{Hidrograf Satuan Sintetik}

Hidrograf satuan sintetik adalah hidrograf satuan yang diturunkan berdasarkan data sungai pada DAS yang sama atau DAS terdekat tetapi memiliki karakteristik yang sama (Kamiana, 2012). Indarto (2016) menyatakan idealnya hidrograf satuan diturunkan dari data hujan dan AWLR, tetapi pada kebanyakan DAS jarang data yang lengkap.

a) Hidrograf Satuan Sintetik Nakayasu

Nakayasu (1950) telah menyelidiki hidrograf satuan di Jepang dan memberikan seperangkat persamaan untuk membentuk suatu hidrograf satuan sebagai berikut:

$$
\begin{aligned}
& Q_{p}=\frac{1}{3,6}\left(\frac{A \mathrm{Re}}{0,3 T p+T_{0,3}}\right) \\
& T_{p}=t_{g}+0,8 T_{r} \\
& t_{g}=0,4+0,058 L L>15 \mathrm{~km}
\end{aligned}
$$




$$
\begin{aligned}
& t_{g}=0,21 L^{0,7} \ldots L<15 \mathrm{~km} \\
& T_{0,3}=\alpha t_{g} \ldots \ldots \ldots \ldots \ldots \ldots \ldots \ldots \ldots \ldots \ldots \ldots \ldots \ldots \ldots \ldots \\
& T_{r}=0,5 t_{g} \text { sampai } t_{g} \ldots \ldots \ldots \ldots \ldots
\end{aligned}
$$

dengan:

$Q_{p} \quad=$ Debit puncak banjir

$A \quad=$ Luas DAS $\left(\mathrm{km}^{2}\right)$

$R_{e} \quad=$ Curah hujan efektif $(1 \mathrm{~mm})$

$T_{p} \quad=$ Waktu dari permulaan banjir sampai puncak hidrograf (jam)

$T_{0,3} \quad=$ Waktu dari puncak banjir sampai 0,3 kali debit puncak (jam)

$t_{g} \quad=$ Waktu konsentrasi (jam)

$T_{r} \quad$ =Satuan waktu dari curah hujan (jam)

$\alpha \quad=$ Koefisien karakteristik DAS biasanya diambil 2

$L \quad=$ Panjang sungai utama $(\mathrm{km})$

Bentuk hidrograf satuan diberikan oleh persamaan berikut:

$$
Q_{t}=Q_{p}\left(\frac{t}{T_{p}}\right)^{2,4}
$$

Pada kurva $\left(T_{p}<t<T_{p}+T_{0,3}\right)$

$$
Q_{r}=Q_{p} \times 0,3^{\left(t-T_{p}\right) / T_{0,3}}
$$

Pada kurva turun $\left(T_{p}+T_{0,3}<t<T_{p}+T_{0,3}\right.$

$$
\begin{aligned}
& \left.+1,5 T_{0,3}\right) \\
Q_{r}= & Q_{p} \times 0,3^{\left\lfloor\left(t-T_{p}\right)+\left(0,5 T_{0,3}\right)\right] /\left(1,5 T_{0,3}\right)}
\end{aligned}
$$

Pada kurva turun $\left(t>T_{p}+T_{0,3}+1,5 T_{0,3}\right)$

$$
Q_{r}=Q_{p} \times 0,3^{\left\lfloor\left(t-T_{p}\right)+\left(0,5 T_{0,3}\right)\right\rfloor /\left(2 T_{0,3}\right)}
$$

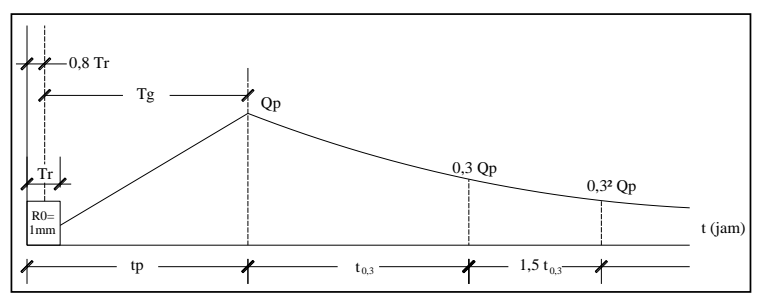

Sumber: Bambang Triadmodjo, 2014

Gambar 1 Hidrograf satuan sintetik

Nakayasu b) Hidrograf Satuan Sintetik Snyder Snyder (1938) mendapatkan dan mengembangkan hidrograf satuan DAS di Amerika Serikat yang berukuran 30 sampai $\quad 30.000 \quad \mathrm{~km}^{2}$ dengan menghubungkan unsur-unsur hidrograf satuan dengan karanteristik DAS akibat hujan $1 \mathrm{~cm}$. Persamaan berikut:

$$
t_{p}=C_{t}\left(L L_{c}\right)^{0,3}
$$

$Q_{p}=\frac{C_{p} A}{t_{p}}$

$T=3+\frac{t_{p}}{8}$

$t_{D}=\frac{t_{p}}{5,5}$

Apabila durasi hujan efektif $t_{p}$ tidak sama dengan durasi standar $t_{D}$, maka:

$$
\begin{aligned}
& t_{p R}=t_{p}+0,25\left(t_{r}-t_{D}\right) \\
& Q_{p R}=Q_{p} \frac{t_{p}}{t_{p R}}
\end{aligned}
$$

dengan:

$t_{D} \quad=$ Durasi standar dari hujan efektif (jam)

$t_{r} \quad=$ Durasi hujan efektif (jam)

$t_{p} \quad=$ Waktu dari titik berat durasi hujan efeftif $t_{D}$ ke puncak hidrograf satuan (jam)

$t_{p R}=$ Waktu dari titik berat durasi hujan $t_{r}$ ke puncak hidrograf satuan (jam)

$T$ =Waktu dasar hidrograf satuan (jam)

$Q_{p} \quad=$ Debit puncak untuk durasi $t_{D}$

$Q_{p R}=$ Debit puncak untuk durasi $t_{r}$

$L \quad=$ Panjang sungai utama terhadap titik kontrol yang ditinjau $(\mathrm{km})$ 
$L_{c} \quad=$ Jarak antara titik kontrol ke titik yang terdekat dengan titik berat DAS $(\mathrm{km})$

$A \quad=$ Luas DAS $\left(\mathrm{km}^{2}\right)$

$C_{t} \quad=$ Koefisien yang tergantung kemiringan DAS (0,75 sampai 3)

$C_{p} \quad=$ Koefisien yang tergantung pada karakteristik DAS $(0,9$ sampai 1,4$)$

Dengan menggunakan rumus-rumus tersebut di atas dapat digambarkan hidrograf satuan. Untuk memudahkan penggambaran, beberapa rumus diberikan sebagai berikut:

$$
\begin{aligned}
& W_{50}=\frac{0,23 A^{1,08}}{Q_{p R}^{1,08}} . \\
& W_{75}=\frac{0,13 A^{1,08}}{Q_{p R}^{1,08}} .
\end{aligned}
$$

Dengan $W_{50}$ dan $W_{75}$ adalah lebar unit hidrograf pada debit $50 \%$ dan $75 \%$ dari debit puncak, yang dinyatakan dalam jam.

c) Hidrograf Satuan Gama I

Hidrograf satuan sintetis Gama I dikembangkan oleh Sri Harto (1993, 2000) berdasar perilaku hidrologis 30 DAS di Pulau Jawa. Meskipun diturunkan dari DAS di Pulau Jawa, ternyata hidrograf satuan sintetis Gama I juga berfungsi baik untuk berbagai daerah lain di Indonesia. HSS Gama I terdiri dari empat variabel pokok, yaitu waktu naik (time of rise - TR), debit puncak $\left(Q_{p}\right)$, waktu dasar $(T B)$ dan sisi resesi yang ditentukan oleh nilai koefisien tampungan $(K)$ yang mengikuti persamaan berikut: $Q_{t}=Q_{p} e^{-t / K}$

dengan:

$Q_{t} \quad=$ Debit pada jam ke $t\left(\mathrm{~m}^{3} / d\right)$

$Q_{p} \quad=$ Debit puncak $\left(\mathrm{m}^{3} / d\right)$ $t=$ Waktu dari saat terjadinya debit pucak (jam)

$K=$ Koefisien tampungan (jam)

Untuk menghitung Hidrograf Gama I dapat digunakan persamaan-persamaan berikut:

Waktu puncak HSS Gama I (TR)

$T R=0,43\left(\frac{L}{100 S F}\right)^{3}+1,0665 S I M+1,2775(29)$

1) Debit puncak banjir $(Q P)$ $Q P=0,1836 A^{0,5886} T R^{-0,4008} J N^{0,2381(30)}$

2) Waktu dasar $(T B)$

$T B=27,4132 T^{0,1457} S^{-0,0986} S N{ }^{0,7344} R U A{ }^{0,2574}(31)$

3) Koefisien resesi $(K)$

$$
K=0,5617 A^{0,1798} S^{-0,1446} S F^{-1,0897} D^{0,0452}
$$

4) Aliran dasar $(Q B)$

$$
Q B=0,4715 A^{0,6444} D^{0,8430}
$$

dengan:

$A \quad=$ Luas DAS $\left(\mathrm{km}^{2}\right)$

$L \quad=$ Panjang sungai utama $(\mathrm{km})$

$S \quad=$ Kemiringan dasar sungai

$S F$ =Faktor sumber, perbandingan antara jumlah panjang pangsa sungai tingkat satu dengan jumlah panjang sungai tingkat

$S N=$ Frekuensi sumber, perbandingan antara jumlah pangsa sungai tingkat satu dengan jumlah pangsa sungai semua tingkat

$W F=$ Faktor lebar, perbandingan antara lebar DAS yang diukur di titik sungai berjarak $0,75 L$ dengan lebar DAS yang diukur di sungai yang berjarak $0,25 \quad L$ dari stasiun hidrometri (Gambar 2.16).

$J N=$ Jumlah pertemuan sungai 
SIM =Faktor simetri, hasil kali antara faktor lebar $(W F)$ dengan luas DAS sebelah hulu (RUA)

$R U A=$ Luas DAS sebelah hulu, perbandingan antara luas DAS yang diukur di hulu garis yang ditarik tegak lurus garis hubungan antara stasiun hidrometri dengan titik yang paling dekat dengan titik berat DAS, melalui titik tersebut (Gambar 2.16).

$D \quad=$ Kerapatan jaringan kuras, jumlah panjang sungai semua tingkat tiap satuan luas.

d) Hidrograf Satuan Sintetik Limantara

Hidrograf satuan sintetik limantara, yang asalnya dari Indonesia, ditemukan oleh Lily Montarcih Limantara pada tahun 2006. Lokasi penelitian di sebagian Indonesia dianggap mewakili : Jawa (6 DAS, 67 Sub DAS), Bali (2 DAS, 13 Sub DAS), Lombok (1 DAS, 5 Sub DAS) dan Kalimantan Timur (1 DAS, 9 Sub DAS). Untuk persamaan- persamaan yang digunakan Hidrograf Satuan Sintetik Limantara berikut:

1) Debit puncak

$Q p=0,042 \cdot A^{0,451} \cdot L^{0,497} \cdot L c^{0,356} \cdot S^{-0,131} \cdot n^{0,168}$

dengan

$Q p \quad=$ debit puncak banjir hidrograf satuan $\left(\mathrm{m}^{3} /\right.$ det $)$

$A \quad=$ luas DAS $\left(\mathrm{km}^{2}\right)$

$L \quad=$ panjang sungai utama $(\mathrm{km})$

$L c \quad=$ kemiringan sungai utama

$n \quad=$ koefisien kekasaran DAS

2) Persamaan kurva naik

$Q_{n}=Q p \cdot\left[\left(t / T_{p}\right)\right]^{1,107}$

dengan
$Q_{n} \quad=$ debit pada persamaan kurva naik $\left(\mathrm{m}^{3} / \mathrm{det}\right)$

$Q p \quad=$ debit puncak banjir hidrograf satuan $\left(\mathrm{m}^{3} / \mathrm{det}\right)$

$t \quad=$ waktu hidrograf (jam)

$T p \quad=$ waktu naik hidrograf atau waktu mencapai puncak hidrograf (jam)

3) Persamaan kurva turun

$Q_{t}=Q p \cdot 10^{0,175(T p-t)}$

dengan

$Q_{t} \quad=$ debit pada persamaan kurva turun ( $m 3 /$ det $)$

$Q p \quad=$ debit puncak hidrograf satuan (m3/det)

$T p \quad=$ waktu naik hidrograf atau waktu mencapai puncak hidrograf (jam)

$t \quad=$ waktu hidrograf (jam)

4) Perkiraan waktu puncak banjir (Tp) Untuk memperkirakan waktu puncak banjir (Tp) bisa dipakai rumus seperti pada Nakayasu berikut:

$T p=t g+0,8 t r$

dengan

Tp =tengangan waktu (time lag) dari permulaan hujan sampai puncak banjir (jam)

$\operatorname{tg}=$ waktu konsentrasi hujan (jam), untuk menentukannya dapat digunakan persamaan berikut : Jika,

$\mathrm{L} \geq 15 \mathrm{~km}$, maka $t g=0,40+0,058 L$...(38)

$\mathrm{L}<15 \mathrm{~km}$, maka ${ }^{t g}=0,21 \mathrm{~L}^{0,7}$

$\mathrm{T}_{\mathrm{r}}=0,5 \mathrm{t}_{\mathrm{g}}$ sampai $\mathrm{t}_{\mathrm{g}}$

e) Hidrograf Satuan Sintetik SCS

SCS menggunakan hidrograf tak berdimensi yang dikembangkan dari 
analisis sejumlah besar hidrograf satuan dari data lapangan dengan berbagai ukuran DAS dan lokasi berbeda. Ordinat hidrograf satuan untuk periode waktu berbeda dapat diperoleh dari tabel berikut, dengan nilai (Gupta, 1989):

$$
\begin{aligned}
& Q_{p}=\frac{0,208 \mathrm{~A}}{T_{p}} \text {. } \\
& T_{p}=\frac{t_{r}}{2}+t_{g} \\
& t_{c}=\left(\frac{0,87 \times L^{2}}{1000 \times S}\right)^{0,385} \\
& t_{g}=0,6 \times t_{c} \\
& t_{r}=0,133 \times t_{c}
\end{aligned}
$$

dengan

$\mathrm{Q}_{\mathrm{p}} \quad=$ debit puncak $\left(\mathrm{m}^{3} / \mathrm{det}\right)$

A =luas DAS $\left(\mathrm{km}^{2}\right)$

$\mathrm{T}_{\mathrm{p}} \quad$ =waktu puncak (jam)

$\mathrm{S} \quad=$ kemiringan sungai utama

$\mathrm{t}_{\mathrm{g}} \quad=$ lag time (jam)

$\mathrm{t}_{\mathrm{r}} \quad=$ durasi hujan efektif (jam)

Tabel 1 Hidrograf satuan metode SCS

\begin{tabular}{|l|l|l|l|l|l|}
\hline$t / p_{r}$ & $Q / Q_{p}$ & $t / p_{r}$ & $Q / Q_{p}$ & $t / p_{r}$ & $Q / Q_{p}$ \\
\hline 0 & 0 & 1,0 & 1,0 & 2,4 & 0,18 \\
0,1 & 0,015 & 1,1 & 0,98 & 2,6 & 0,13 \\
0,2 & 0,075 & 1,2 & 0,92 & 2,8 & 0,098 \\
0,3 & 0,16 & 1,3 & 0,84 & 3,0 & 0,075 \\
0,4 & 0,28 & 1,4 & 0,75 & 3.5 & 0,036 \\
0,5 & 0,43 & 1,5 & 0,66 & 4,0 & 0,018 \\
0,6 & 0,60 & 1,6 & 0,56 & 4,5 & 0,009 \\
0,7 & 0,77 & 1,8 & 0,42 & 5,0 & 0,004 \\
0,8 & 0,89 & 2,0 & 0,32 & & 0 \\
0,9 & 0,97 & 2,2 & 0,24 & & \\
\hline
\end{tabular}

Sumber : Triadmodjo, 2014

\section{G. Kalibrasi Model Hidrograf Debit}

RMSE (root mean square erorr) merupakan metode alternatif untuk mengevaluasi teknik peramalan yang digunakan untuk mengukur tingkat akurasi hasil perkiraaan suatu model. Parameter model yang dipilih bila dengan uji statistik diperoleh nilai RMSE (root mean square erorr) yang kurang dari $10 \%$ (Soewarno, 2013). RMSE dapat dihitung dengan rumus:

$R M S E=\sqrt{\sum_{1}^{n}\left(\frac{Q e-Q o}{n}\right)^{2}}$

dengan :

RMSE $=$ Root Mean Square Error

$Q e=$ Debit estimasi $\left(\mathrm{m}^{3} / \mathrm{det}\right)$

$Q o=$ Debit observasi $\left(\mathrm{m}^{3} / \mathrm{det}\right)$

$n=$ Jumlah pengamatan

\section{H. Korelasi}

Korelasi adalah istilah statistik yang menyatakan derajat hubungan linier antara dua variabel atau lebih, yang ditemukan oleh Karl Pearson pada awal 1900 dan dikenal dengan Korelasi Pearson Product Moment (PPM), (Susanti, 2014).

Untuk data kualitatif dalam mengukur kuatnya hubungan disebut Contigency Coefficient (koefisien bersyarat, $\mathrm{Cc}$ ). Adapun batas ketentuan $\mathrm{Cc}$ sebagai berikut:

a. Jika nilai perbandingan $\mathrm{Cc}$ dengan batas $<0,50$ maka hubungan lemah

b. Jika nilai Cc antara 0,50 dan 0,75 maka hunbungan sedang/ cukup

c. Jika nilai Cc antara 0,75 dan 0,90 maka hubungan kuat

d. Jika nilai $\mathrm{Cc}$ anata 0,90 dan 1 maka hubungan sangat kuat

e. Jika nilai $\mathrm{Cc}=1$ maka hubungan sempurna 


\section{METODE PENELITIAN}

\section{A. Lokasi Penelitian}

Secara geografis Sub Sub DAS Pedindang berada pada $106^{\circ} 00^{\prime} \mathrm{BT}$ sampai $106^{\circ} 10^{\prime}$ BT dan $2^{\circ} 05^{\prime}$ LS sampai $2^{\circ} 15^{\prime}$ LS.

Sub DAS Pedindang mempunyai panjang 15,93 km yang membentang dan memotong dua daerah administrasi, yaitu hulu sungai berada di Desa Mangkol Kabupaten Bangka Tengah dan hilir sungai berada di Stasiun Pengukuran Tinggi Muka Air (AWLR) Kota Pangkalpinang. Sub Sub DAS Pedindang mempunyai luas DAS yaitu dengan luas $35,14 \mathrm{~km}^{2}$.

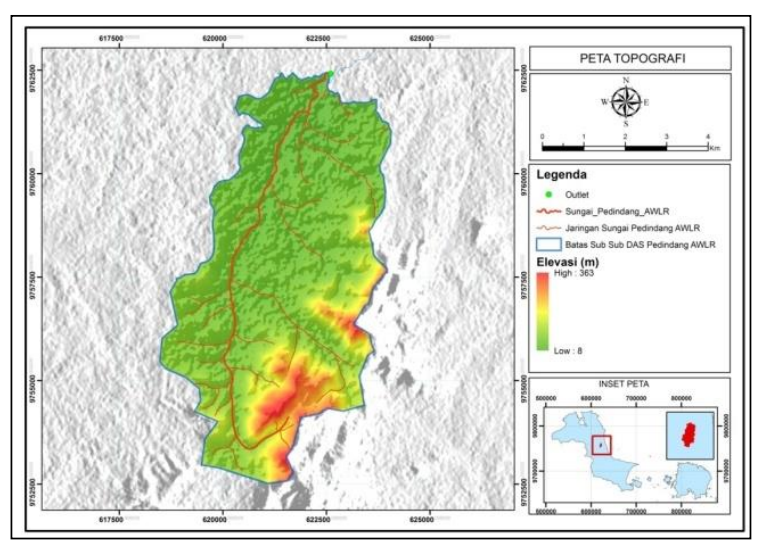

Sumber : Data diolah, 2018

Gambar 2 Bentuk Sub Sub DAS

Pedindang

Mata air Sungai Pedindang berada di Gunung Mangkol (397,5 mDPL). Dari Gunung Mangkol, Sungai Pedindang mengalir menuju timur laut melewati Kolong Pedindang di Desa Parit Lalang. Kolong Pedindang adalah kolong yang dipergunakan sebagai salah satu sumber air baku untuk Kota Pangkalpinang. Sungai Pedindang bermuara di Kolong Pasar Ikan yang berada di Kota
Pangkalpinang sebelum bertemu dengan Sungai Rangkui.

\section{B. Alat dan Bahan}

Alat yang digunakan dalam penelitian ini berupa seperangkat komputer dengan software, AutoCAD, meteran, GPS, Stopwatch, Microsoft Excel 2013, ArcGIS 10.1. Sedangkan data yang diperlukan dalam penelitian ini meliputi:

1) Data karakteristik Sub Sub DAS Pedindang.

2) Data hujan jam-jaman Stasiun BMKG dan Stasiun Cuaca Univesitas Bangka Belitung periode 1 Februari 2016 s.d. 7 Maret 2016.

3) Data tinggi muka air jam-jaman Kementerian SDA Wil. Sungai Sumatera VIII periode 1 Februari 2016 s.d. 7 Maret 2016.

4) Data primer Sungai Pedindang yaitu, kecepatan, luas penampang, dan debit.

\section{Diagraf Alir}

Diagram alir (flowchart) penelitian yang digunakan dalam penelitian ini tersaji seperti pada Gambar 3.

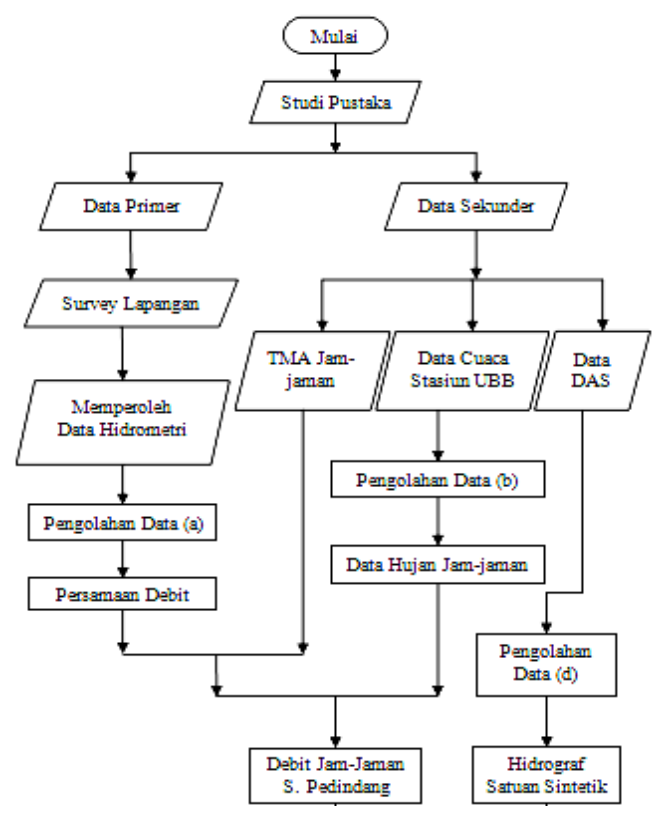




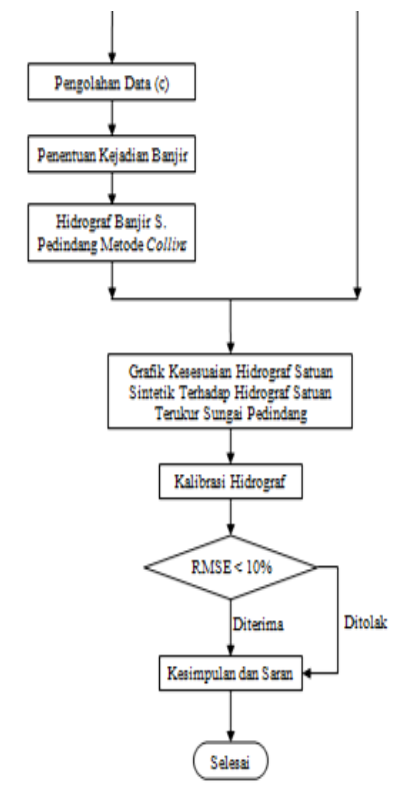

Gambar 3 Diagram alir (flowchart) penelitian

\section{ANALISIS DAN PEMBAHASAN}

\section{A. Analisis Hidrometri}

1. Pengukuran Tampang Sungai

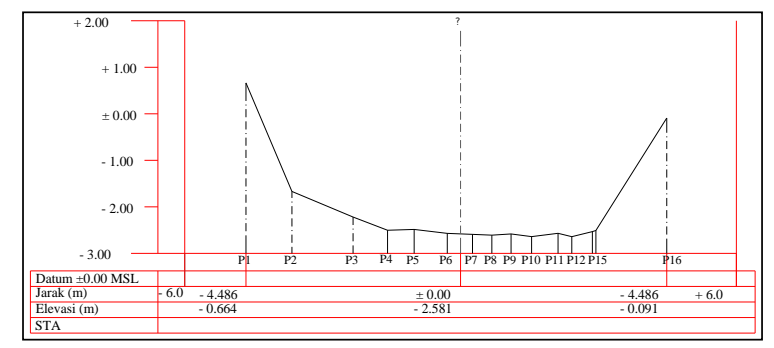

Sumber : Hasil analisis, 2017

Gambar 4 Bentuk Sub Sub DAS Pedindang

Pengukuran tampang sungai ini dilakukan bersamaan dengan mengukur tinggi muka air. Dari pengukuran tinggi muka air tersebut akan mendapatkan luas penampang basah yang akan digunakan untuk menghitung debit aliran.

\section{Perhitungan Debit Aliran Air}

Perhitungan debit aliran air dapat dihitung setelah memperoleh data tinggi muka air, luas tampang basah serta kecepatan aliran air. Debit dihitung berdasarkan data tersebut yang diukur 1 hari sebanyak 3 kali yaitu waktu pagi, siang dan sore selama 30 hari.

Tabel 2 Peritungan kecepatan aliran air

\begin{tabular}{|c|c|c|c|c|c|}
\hline \multirow{2}{*}{ No } & \multicolumn{3}{|c|}{ Percobaan (det) } & \multirow{2}{*}{$\begin{array}{c}\text { Kecepatan } \\
\text { rata-rata (det) }\end{array}$} & \multirow{2}{*}{$\begin{array}{c}\text { Panjang } \\
\text { lintasan }(\mathrm{m})\end{array}$} \\
\hline & Lin. I & Lin. II & Lin. III & & \\
\hline $\mathrm{a}$ & $\mathrm{b}$ & $\mathrm{c}$ & d & $e=\operatorname{avg}(b: c: d)$ & $f$ \\
\hline 1 & 42,32 & 2,37 & 42,25 & 42,3133 & 27,462 \\
\hline 2 & 31,22 & 31,24 & 31,27 & 31 & 27,462 \\
\hline 3 & 48,23 & 48,33 & 48,29 & 48,2833 & 27,462 \\
\hline
\end{tabular}

Sumber : Hasil analisis, 2017

Tabel 3 Perhitungan debit aliran air

\begin{tabular}{|c|c|c|c|c|c|}
\hline No & $\begin{array}{c}\text { Kecepatan, } \\
V_{F}(\mathrm{~m} / \mathrm{det})\end{array}$ & $\begin{array}{c}\text { Faktor } \\
\text { koreksi, } \boldsymbol{k}\end{array}$ & $\begin{array}{c}\text { Kecepatan } \\
\text { koreksi, } v \\
(\mathrm{~m} / \mathrm{det})\end{array}$ & $\begin{array}{c}\text { Luas, } \boldsymbol{a} \\
\left(\mathrm{m}^{2}\right)\end{array}$ & $\begin{array}{c}\text { Debit, } \boldsymbol{Q} \\
\left(\mathrm{m}^{3 / / d e t}\right)\end{array}$ \\
\hline $\mathrm{g}$ & $\mathrm{h}=\mathrm{f} / \mathrm{e}$ & $\mathrm{i}$ & $\mathrm{j}=\mathrm{h} / \mathrm{i}$ & $\mathrm{k}$ & $1=\mathrm{j}^{\mathbf{8}} \mathrm{k}$ \\
\hline 1 & 0,6490 & 0,85 & 0,5517 & 1,3555 & 0,7478 \\
\hline 2 & 0,8773 & 0,85 & 0,7457 & 1,4497 & 1,0810 \\
\hline 3 & 0,5688 & 0,85 & 0,4835 & 0,8535 & 0,4126 \\
\hline & \multicolumn{5}{|c|}{ Total $=$} \\
\hline
\end{tabular}

Sumber : Hasil analisis, 2017

Adapun contoh rekapitulasi data pengukuran debit aliran air terlampir pada Lampiran-5.

\section{B. Persamaan Lengkung Debit}

Dari perhitungan debit diperoleh sebanyak 90 data pengukuran debit. Tahap perhitungan dalam pembuatan lengkung debit sebagai berikut:

\section{Menentukan harga $\mathrm{H}_{0}$}

Menetukan harga $\mathrm{H}_{0} \quad$ dengan menggunakan cara aritmatik, berdasarkan persamaan (6) dan (7) sebagai berikut: $\mathrm{H}_{1}=0,6347 \mathrm{~m}$ dan $\mathrm{Q}_{1}=1,8966 \mathrm{~m}^{3} /$ det $\mathrm{H}_{3}=1,0245 \mathrm{~m}$ dan $\mathrm{Q}_{3}=4,4046 \mathrm{~m}^{3} /$ det Berdasarkan persamaan (6), maka:

$\mathrm{Q}_{2}=(1,8966 \times 4,4046)^{0,5}=2,8903 \mathrm{~m}^{3} / \mathrm{det}$ dan untuk mencari $\mathrm{H}_{2}$ dengan cara interpolasi linier sebagai mendapatkan nilai $\mathrm{H}_{2}=0,7891 \mathrm{~m}$.

Setelah didapatkan nilai $\mathrm{H}_{2}$, maka berdasarkan persamaan (7) didapatkan $\mathrm{H}_{0}$ sebesar : 


$$
\begin{aligned}
& H_{0}=\frac{(0,6347 \times 1,0245)-(0,7891)^{2}}{(0,6347+1,0245)-(2 \times(0,7891))} \\
& H_{0}=0,3399 \mathrm{~m}
\end{aligned}
$$

Hasil perhitungan secara keseluruhan telampir pada Lampiran-3, dan diperoleh hasil sebagai berikut:

$$
\begin{array}{ll}
\Sigma(\mathrm{x}) & : \mathbf{- 4 1 , 5 0 4 7} \\
\Sigma(\mathrm{y}) & : \mathbf{3 0 , 8 9 9 1} \\
\Sigma(\mathrm{xy}) & : \mathbf{- 1 3 , 5 3 7 4} \\
\Sigma\left(\mathrm{x}^{2}\right) & : \mathbf{1 9 , 8 7 6 3} \\
\mathrm{m} \quad: \mathbf{9 0}
\end{array}
$$

\section{Menetukan nilai $\mathrm{K}$ dan $\mathrm{n}$}

Setelah mendapatkan nilai tersebut, langkah selanjutnya menentukan nilai $K$ dan $n$, berdasarkan persamaan (8) dan (9) maka diperoleh sebagai berikut:

$$
\begin{aligned}
& 30,8991-90 \log K+41,5047 n=0 . . \\
& -13,5374+41,5047 \log K-19,8763 n=0
\end{aligned}
$$

Dengan persamaan (47) dan persamaan (48), untuk memperoleh nilai $\mathrm{K}$ dan $\mathrm{n}$ digunakan metode eliminasi dan substitusi dan mendapatkan nilai $K=6,1597$ dan $n=$ 0,9676. Dengan nilai $\mathrm{H}_{0}, \mathrm{~K}$ dan $\mathrm{n}$ tersebut maka diperoleh persamaan lengkung debit Sungai Pedindang untuk tanggal 2 Agustus 2017 sampai dengan 31 Agustus 2017 menurut persamaan (5) adalah $\mathbf{Q}=$ 6,1597 (H - 0,3399) ${ }^{\mathbf{0 , 9 6 7 6}}$.

\section{Data Hujan}

Data Data hujan berupa data curah hujan jam-jaman yang dilakukan analisis korelasi antara data hujan per 3 jam-an pada Stasiun Iklim Univesitas Bangka Belitung terhadap Stasiun Meteorologi Kelas I Depati Amir Kota Pangkalpinang. Analisis ini dilakukan untuk menetukan seberapa kuat hubungan antara kedua data hujan tersebut.

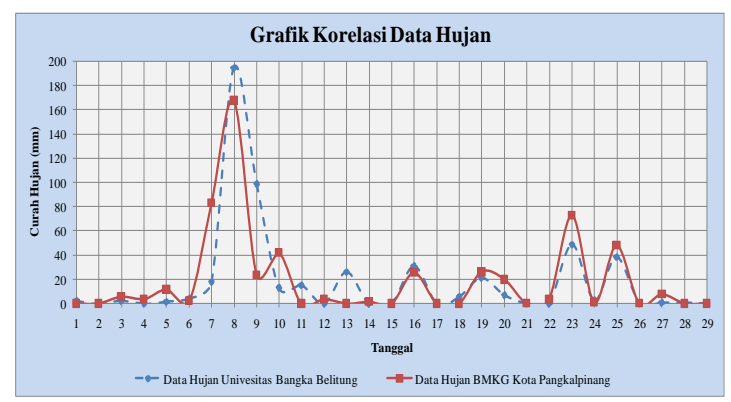

Sumber : Hasil analisis, 2017

Gambar 5 Grafik korelasi data hujan antar stasiun

Dari grafik curah hujan per 3 jam-an kemudian dianalisis menggunkaan metode korelasi. Dengan metode korelasi menggunakan microsoft excel diperoleh hasil sebagai berikut.

Tabel 4 Nilai korelasi data hujan antar

\begin{tabular}{|l|l|l|l|}
\hline \multicolumn{3}{|c|}{ stasiun } \\
\hline Data & $\begin{array}{c}\text { Data Hujan } \\
\text { UBB }\end{array}$ & 1 & $\begin{array}{l}\text { Data Hujan } \\
\text { BMKG }\end{array}$ \\
\hline $\begin{array}{cc}\text { UBB } \\
\text { Data }\end{array}$ & $\begin{array}{c}\text { Hujan } \\
\text { BMKG }\end{array}$ & 0,837965 & 1 \\
\hline
\end{tabular}

Sumber : Hasil analisis, 2018

Dari Tabel 4 diperoleh nilai korelasi antara data hujan Stasiun Iklim Univesitas Bangka Belitung terhadap data hujan Stasiun Meteorologi Klas I Depati Amir Kota Pangkalpinang sebesar 0,837965, dapat ditarik kesimpulan bahwa, dari hasil tersebut menunjukan data hujan dari kedua stasiun tersebut mempunyai korelasi (hubungan) yang kuat.

\section{Penentuan Kejadian Banjir}

Dari data debit dan hujan Sungai Pedindang didapatkan empat kejadian banjir yaitu tanggal 23-24 Februari 2016, 2-3 Maret 2016, 3-4 Maret 2016 dan 5-6 
Maret 2017. Adapun data penentuan kejadian banjir terlampir pada Lampiran 3.

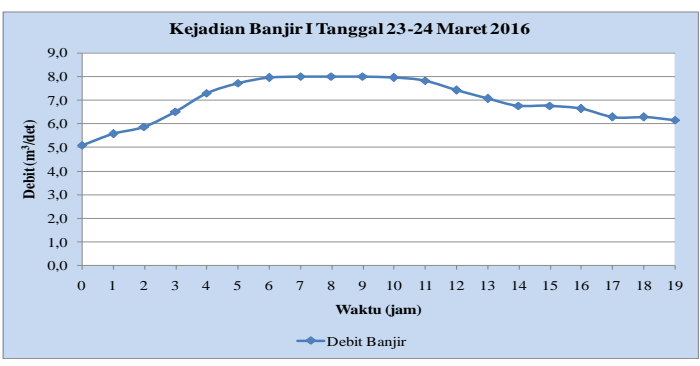

Sumber : Hasil analisis, 2017

Gambar 6 kejadian banjir tanggal 23-24

Februari 2016

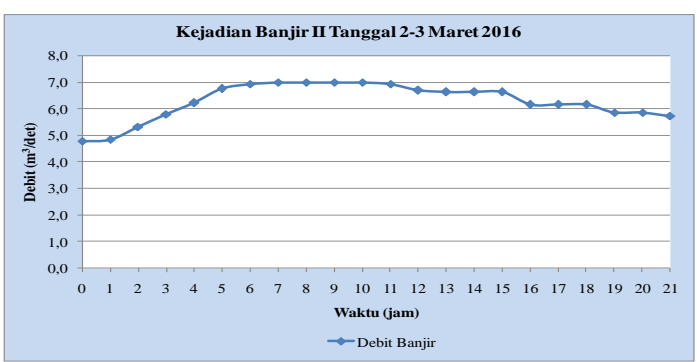

Sumber : Hasil analisis, 2017

Gambar 7 kejadian banjir tanggal 2-3

Maret 2016

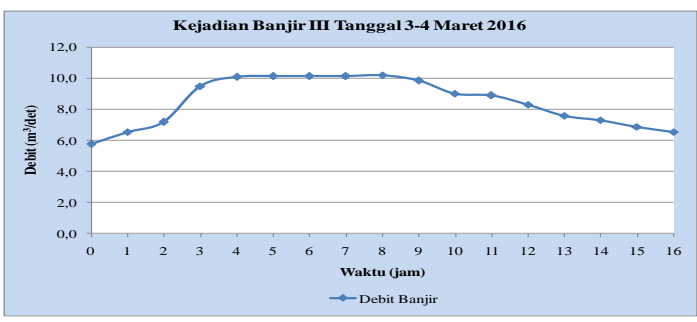

Sumber : Hasil analisis, 2017

Gambar 8 kejadian banjir tanggal 3-4

Maret 2016

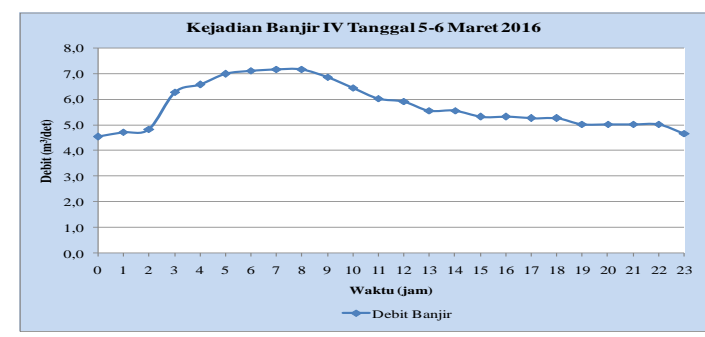

Sumber : Hasil analisis, 2017

Gambar 9 kejadian banjir tanggal 5-6

Maret 2016

\section{E. Hidrograf Collins}

Penentuan kejadian banjir telah diperoleh dan analisis $\Phi_{\text {indeks }}$ telah diperoleh hidrograf limpasan langsung serta hujan efektif, selanjutnya dilakukan analisis hidrograf limpasan langsung dan hujan efektif dengan menggunakan metode Collins. Untuk bentuk

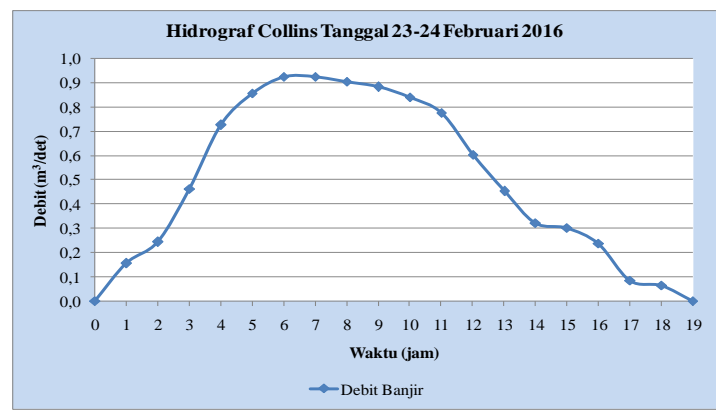

Sumber : Hasil analisis, 2017

Gambar 10 Hidrograf Collins tanggal 2324 Februari 2016

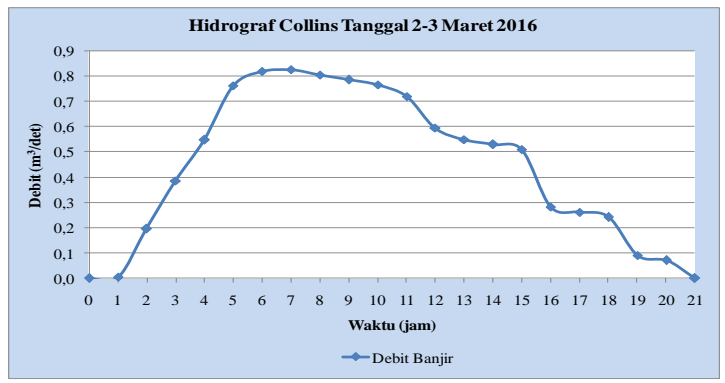

Sumber : Hasil analisis, 2017

Gambar 11 Hidrograf Collins tanggal 2-3

Maret 2016

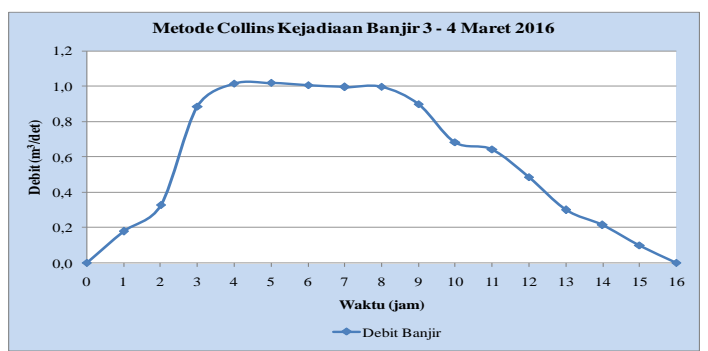

Sumber : Hasil analisis, 2017

Gambar 12 Hidrograf Collins tanggal 3-4 Maret 2016 


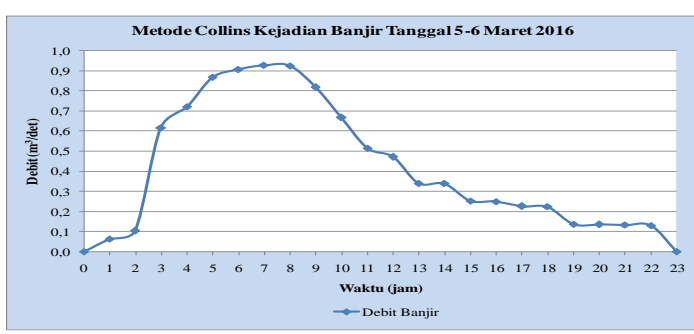

Sumber : Hasil analisis, 2017

Gambar 13 Hidrograf Collins tanggal 5-6 Maret 2016

\section{F. Hidrograf Satuan Sintetik}

Prosedur pembuatan hidrograf satuan sintetik yang digunakan adalah HSS Gama I, HSS Nakayasu, HSS Snyder, HSS Limantara dan HSS SCS.

\section{HSS Gama I}

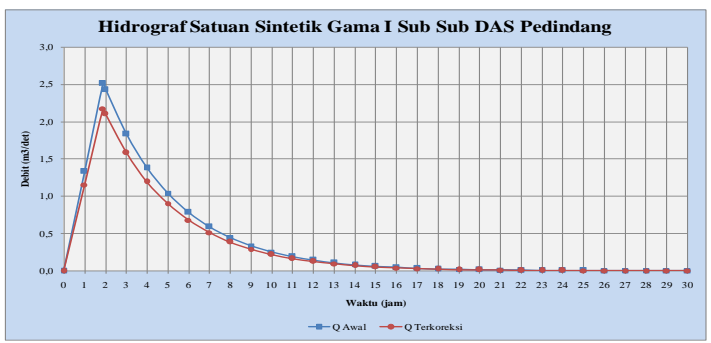

Sumber : Hasil analisis, 2017

Gambar 14 Grafik HSS Gama I Sub Sub DAS Pedindang

\section{HSS Nakayasu}

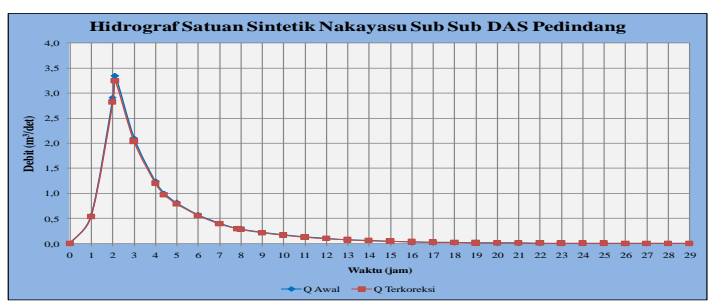

Sumber : Hasil analisis, 2017

Gambar 15 Grafik HSS Nakayasu Sub Sub DAS Pedindang

\section{HSS Snyder}

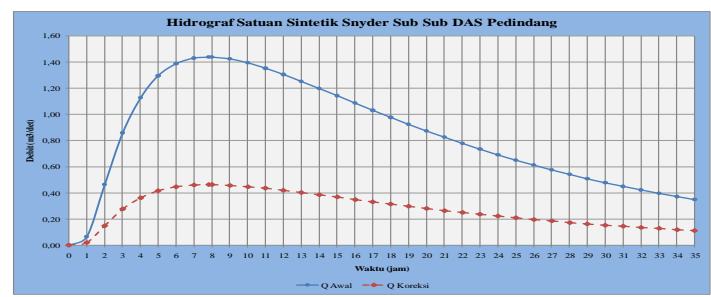

Sumber : Hasil analisis, 2017

Gambar 16 Grafik HSS Snyder Sub Sub DAS Pedindang

4. HSS Limantara

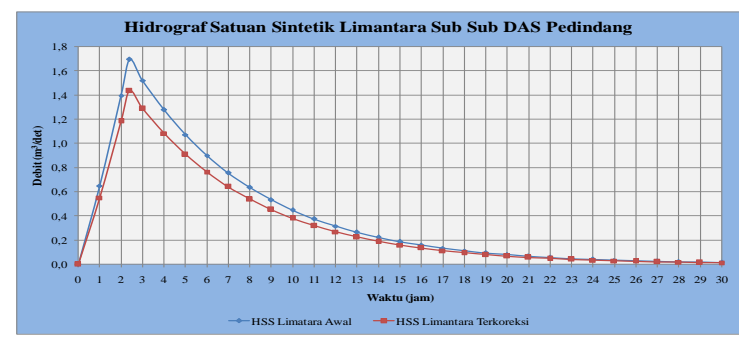

Sumber : Hasil analisis, 2017

Gambar 17 Grafik HSS Limantara Sub Sub DAS Pedindang

\section{HSS SCS}

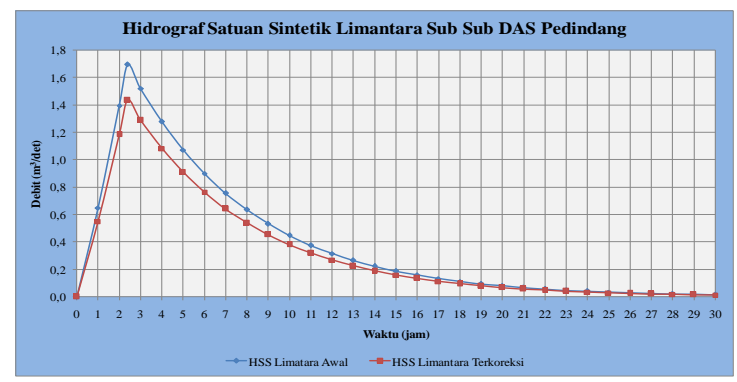

Sumber : Hasil analisis, 2017

Gambar 18 Grafik HSS SCS Sub Sub

DAS Pedindang

\section{G. Kesesuaian Hidrograf Satuan Sintetik Dengan Terukur}

Dari analisis hidrograf satuan Collins diperoleh bentuk hidrograf satuan terukur Sungai Pedindang. Hidrograf satuan terukur yang diperoleh dengan metode hidrograf collins sebanyak 4 kejadian yaitu: kejadian banjir 23-24 Februari 2016, kejadian banjir 2-3 Maret 2016, 
kejadian banjir 3-4 Maret 2016 dan kejadian banjir 5-6 Maret 2016. Untuk bentuk hidrograf satuan sintetik Sub Sub Daerah Aliran Sungai diperoleh dari analisis hidrograf satuan sintetik dengan menggunakan 5 prosedur perhitungan yaitu: HSS Gama I, HSS Nakayasu, HSS Snyder, HSS Limantara dan HSS SCS.

1. Kejadian Banjir 23-24 Februari 2016

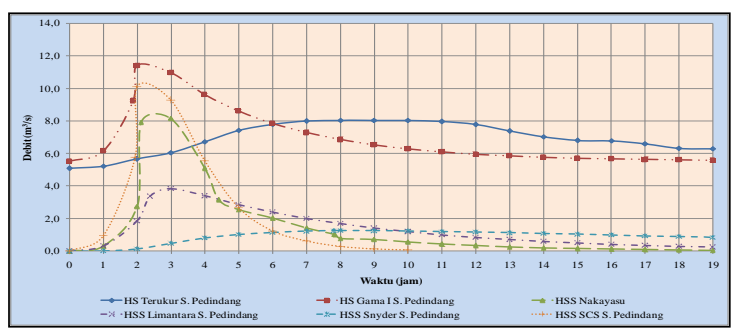

Sumber : Hasil analisis, 2017

Gambar 19 Grafik kesesuaian HSS Sub

Sub DAS Pedindang Terhadap HST

Sungai Pedindang 23-24 Februari 2016

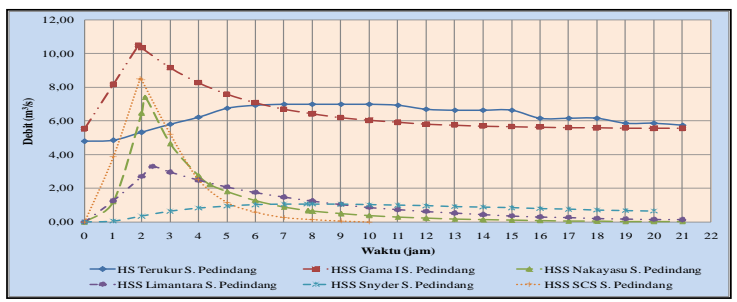

Sumber : Hasil analisis, 2017

Gambar 20 Grafik kesesuaian HSS Sub Sub DAS Pedindang Terhadap HST Sungai Pedindang 2-3 Maret 2016

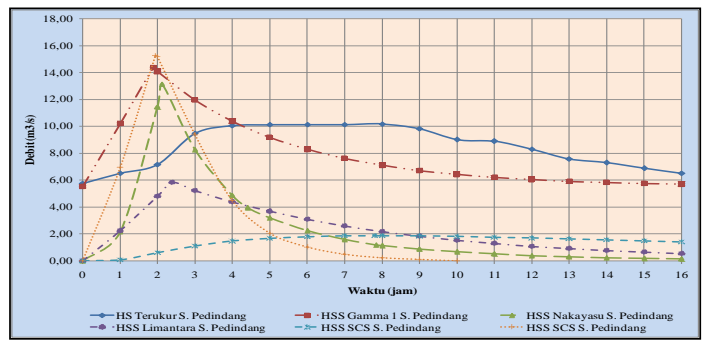

Sumber : Hasil analisis, 2017

Gambar 21 Grafik kesesuaian HSS Sub

Sub DAS Pedindang Terhadap HST

Sungai Pedindang 3-4 Maret 2016

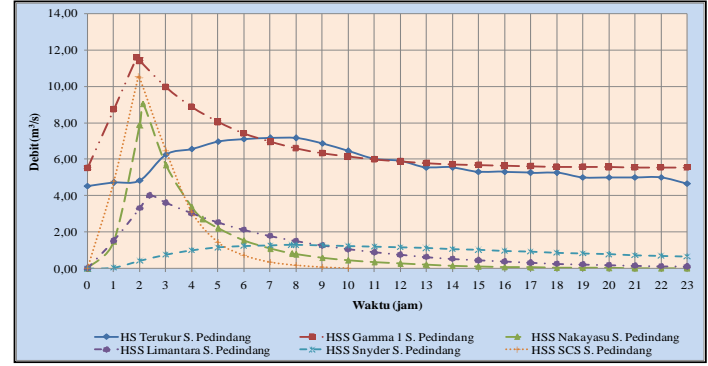

Sumber : Hasil analisis, 2017

Gambar 22 Grafik kesesuaian HSS Sub

Sub DAS Pedindang Terhadap HST

Sungai Pedindang 5-6 Maret 2016

\section{H. Validasi Kesesuaian Hidrograf Metode RMSE}

Metode RMSE membandingkan debit estimasi dengan debit observasi, dimana nilai RMSE kurang dari $(<10 \%)$, maka model tersebut paling sesuai.

1. Kejadian Banjir 23-24 Februari 2016

Tabel 5 Hasil nilai RMSE kejadian banjir I

\begin{tabular}{|r|l|c|c|c|}
\hline \multirow{2}{*}{ No } & \multicolumn{1}{|c|}{ Hidrogr af } & $\mathbf{Q}_{p}$ & $\dagger$ & \multirow{2}{*}{ Niai RMSE } \\
\cline { 3 - 5 } & & $\left(\mathbf{m}^{\mathbf{3}} / \mathrm{det}\right)$ & (jam) & \\
\hline $\mathbf{I}$ & HST Sungai Pedindang & $\mathbf{8 , 0 4 4 5}$ & $\mathbf{8}$ & \\
\hline $\mathbf{2}$ & HSS Gama ISungai Pedindang & $\mathbf{1 1 , 4 1 7 2}$ & $\mathbf{2}$ & $23,601 \%$ \\
\hline $\mathbf{3}$ & HSS Nakayasu Sungai Pedindang & $\mathbf{8 , 1 5 4 6}$ & $\mathbf{3}$ & $4235,709 \%$ \\
\hline $\mathbf{4}$ & HSS Limantara Sungai Pedindang & $\mathbf{3 , 8 3 2 7}$ & $\mathbf{3}$ & $1021,735 \%$ \\
\hline $\mathbf{5}$ & HSS Snyder Sungai Pedindang & $\mathbf{1 , 2 5 3 6}$ & $\mathbf{8}$ & $9096,956 \%$ \\
\hline $\mathbf{6}$ & HSS SCS Sungai Pedindang & $\mathbf{1 0 , 1 2 8 2}$ & $\mathbf{2}$ & $2216,734 \%$ \\
\hline
\end{tabular}

Sumber: Hasil analisis, 2018

2. Kejadian Banjir 2-3 Maret 2016

Tabel 6 Hasil nilai RMSE kejadian banjir II

\begin{tabular}{|c|l|c|c|c|}
\hline \multirow{2}{*}{ No } & \multicolumn{1}{|c|}{ Hidrograf } & $\mathbf{Q}_{\mathrm{p}}$ & $\boldsymbol{\dagger}$ & \multirow{2}{*}{ Niai RMSE } \\
\cline { 3 - 5 } & & $\left(\mathrm{m}^{3} / \mathrm{det}\right)$ & (jam) & \\
\hline $\mathbf{I}$ & HST Sungai Pedindang & $\mathbf{6 , 9 9 2 8}$ & $\mathbf{7}$ & \\
\hline $\mathbf{2}$ & HSS Garna I Sungai Pedindang & $\mathbf{1 0 , 5 0 6 3}$ & $\mathbf{1 , 8 8 5 8}$ & $\mathbf{1 6 , 3 1 5 \%}$ \\
\hline $\mathbf{3}$ & HSS Nakayasu Sungai Pedindang & $\mathbf{7 , 4 1 2 3}$ & $\mathbf{2 , 1 1 6 3}$ & $7273,761 \%$ \\
\hline $\mathbf{4}$ & HSS Limantara Sungai Pedindang & $\mathbf{3 , 2 8 6 2}$ & $\mathbf{2 , 3 8 3 4}$ & $1436,896 \%$ \\
\hline $\mathbf{5}$ & HSS Snyder Sungai Pedindang & $\mathbf{1 , 0 5 7 3}$ & $\mathbf{7 , 8 0 8 9}$ & $2225,258 \%$ \\
\hline $\mathbf{6}$ & HSS SCS Sungai Pedindang & $\mathbf{8 , 5 1 1 7}$ & $\mathbf{1 , 9 3 9 9}$ & $3960,140 \%$ \\
\hline
\end{tabular}

Sumber: Hasil analisis, 2018

3. Kejadian Banjir 3-4 Maret 2016

Tabel 7 Hasil nilai RMSE kejadian banjir III 


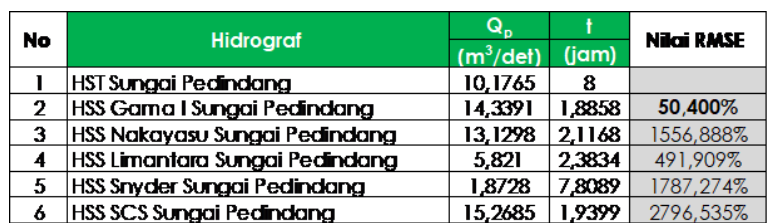

Sumber: Hasil analisis, 2018

4. Kejadian Banjir 5-6 Maret 2016

Tabel 8 Hasil nilai RMSE kejadian banjir IV

\begin{tabular}{|c|c|c|c|c|}
\hline No & Hidrograf & $\frac{Q_{D}}{\left(\mathrm{~m}^{3} / \text { def }\right)}$ & $\frac{t}{\text { (jam) }}$ & Niloi RMSE \\
\hline 1 & HST Sungai Pedindang & 7,1708 & 7 & \\
\hline 2 & HSS Gama I Sungai Pedindang & 11,6034 & 1,8858 & $22,322 \%$ \\
\hline 3 & HSS Nakayasu Sungai Pedindang & 9,0584 & 2,1168 & $8457,439 \%$ \\
\hline 4 & HSS Limantara Sungai Pedindang & 4,016 & 2,38334 & $1419,119 \%$ \\
\hline 5 & HSS Sryder Sungai Pedindang & 1,2921 & 7,80839 & $1537,541 \%$ \\
\hline 6 & HSS SC & & 1,9399 & \\
\hline
\end{tabular}

Sumber: Hasil analisis, 2018

\section{KESIMPULAN DAN SARAN}

\section{A. Kesimpulan}

Berdasarkan hasil analisis dan pembahasan mengenai kesesuaian hidrograf satuan sintetik terhadap hidrograf satuan terukur Sub Sub Daerah Aliran Sungai Pedindang Bagian Tengah maka dapat disimpulkan beberapa hal sebagai berikut:

1. Kesesuaian hidrograf satuan terukur terhadap hidrograf satuan sintetik Sungai Pedindang sangat berbeda satu dengan lainnya, hal ini dapat dilihat pada hasil analisis. Pada hasil analisis untuk setiap kejadian banjir, debit puncak hidrograf satuan sintetik Sungai Pedindang sangat berbeda dengan debit puncak hidrograf satuan terukurnya. Rata-rata debit puncak hidrograf satuan sintetik terjadi pada kisaran 2 atau 3 jam, sedangkan hidrograf satuan terukur Sungai Pedindang terjadi pada kisaran 7 atau 8 jam.

2. Dari keempat kejadian banjir Sungai Pedindang tidak diperoleh nilai
RMSE yang memenuhi syarat kurang dari $10 \%$ (< 10\%), namun yang mendekati syarat hanya satu hidrograf satuan sintetik dengan nilai berikut:

a. Tanggal 23-24 Februari 2016 sebesar 23,601\% adalah Hidrograf Satuan Sintetik Gama I

b. Tanggal 2-3 Maret 2016 sebesar $16,315 \%$ adalah Hidrograf Satuan Sintetik Gama I

c. Tanggal 3-4 Maret 2016 sebesar $50,400 \%$ adalah Hidrograf Satuan Sintetik Gama I

d. Tanggal 5-6 Maret sebesar 22,322\% adalah Hidrograf Satuan Sintetik Gama I

3. Dengan diperolehnya nilai RMSE (validasi) digunakan untuk menyatakan model hidrograf satuan sintetik yang paling sesuai dengan hidrograf satuan terukur Sungai Pedindang. Maka, dari keempat kejadian banjir Sungai Pedindang, tidak ada model hidrograf satuan sintetik mempunyai nilai RMSE < $10 \%$ dan menyatakan bahwa seluruh model hidrograf satuan sintetik tidak berkesesuaian terhadap hidrograf satuan terukur Sungai Pedindang.

\section{B. Saran}

1. Dalam penelitian ini pada analisis kesesuaian bentuk hidrograf satuannya sangat berbeda jauh. Dari hasil analisis, debit puncak hirograf satuan sintetik berada pada kisaran waktu 2 atau 3 jam. Sedangkan pada hidrograf satuan terukur, debit puncak hirograf berada pada kisaran 7 atau 8 jam. Hasil penelitian ini dipengaruhi oleh penentuan kejadian 
banjirnya. Pada penentuan kejadian banjir, data yang digunakan adalah data tinggi muka air dari alat AWLR pada tanggaltanggal yang bukan merupakan puncak banjir pada Sungai Pedindang. Hasil analisis juga dipengaruhi data hujan jamjaman yang digunakan terlalu jauh dari lokasi penelitian, dimana data hujan yang digunakan adalah data hujan dari Stasiun Cuaca Universitas Bangka Belitung. Untuk penelitian selanjutnya, dalam analisis hidrograf satuan terukur sebaiknya digunakan lebih banyak kejadian banjir sebagai acuan serta data hujan yang digunakan adalah data hujan terdekat pada lokasi penelitian.

\section{DAFTAR PUSTAKA}

Asdak, Chay. 2014. Hidrologi dan Pengelolaan Daerah Aliran Sungai. Cetakan Keenam. Yogyakarta: Gadjah Mada University Press.
Kamiana, I Made. 2012. Teknik Perhitungan Debit Rencana Bangunan Air. Cetakan Kedua. Yogyakarta: Graha Ilmu

Soewarno. 2013. Hidrometri Dan Aplikasi

Teknosabo Dalam Pengelolaan Sumber Daya Air. Cetakan Pertama. Yogyakarta: Graha Ilmu.

Soewarno. 2015. Analisisn Data Hidrologi Menggunakan Metode Statitiska dan Stokastik. Cetakan Pertama. Yogyakarta: Graha Ilmu

Sri Harto. 2000. Hidrologi: Teori, Masalah, Penyelesaian. Cetakan Pertama. Yogyakarta: Beta Offset. Susanti, Meilia Nur Indah. 2014. Statistika Deskriptif \& Induktif. Cetakan Kedua. Yogyakarta: Graha Ilmu.

Triatmodjo, Bambang. 2014. Hidrologi Terapan. Cetakan Keempat. Yogyakarta: Beta Offset. 